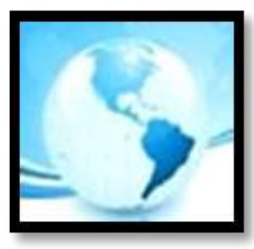

MALAYSIAN ONLINE JOURNAL OF

EDUCATIONAL MANAGEMENT

(MOJEM)

January 2020, VOLUME 8, ISSUE 1, 39-57

E-ISSN NO: $2289-4489$

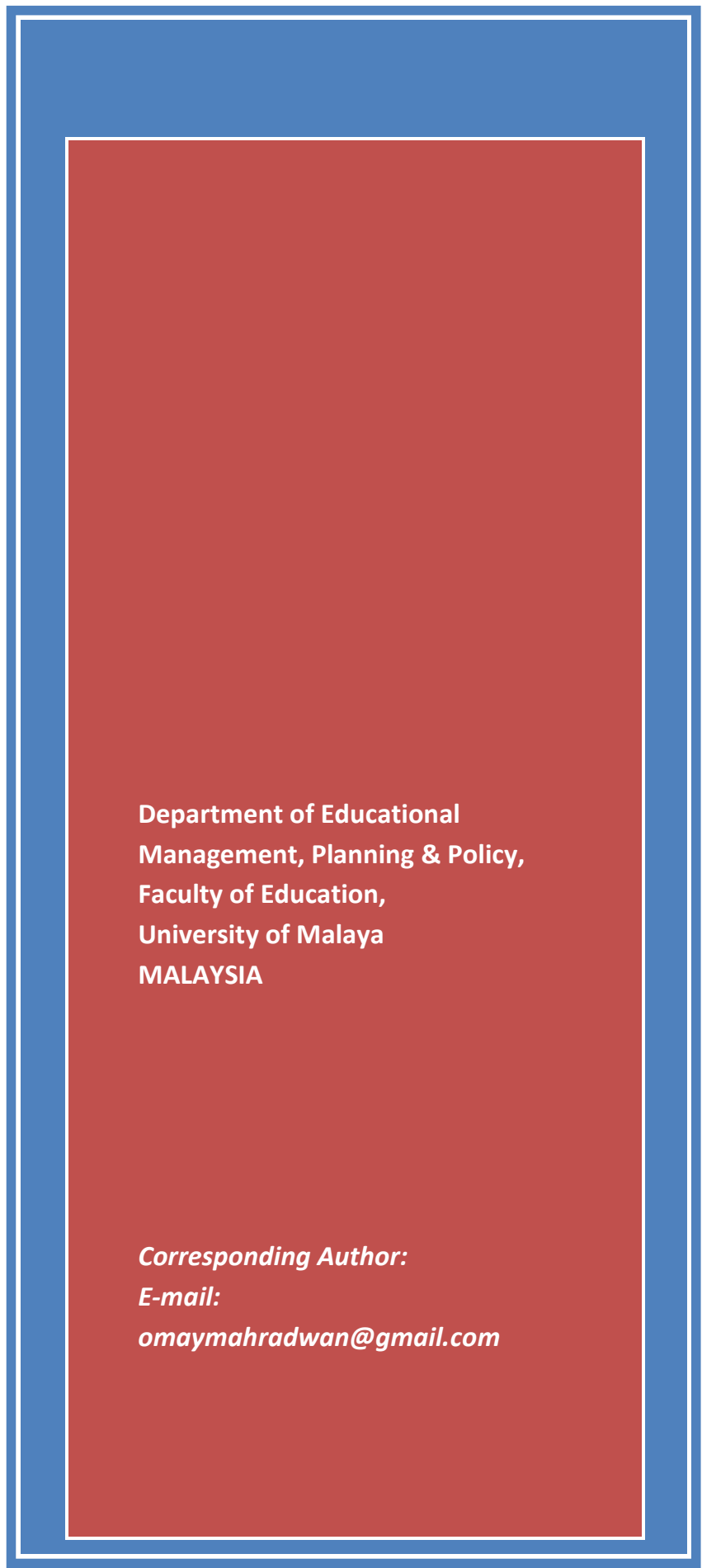

\section{THE MEDIATING EFFECT OF ORGANISATIONAL CULTURE ON ACADEMIC LEADERSHIP SKILLS AND STUDENTS' SKILL-BASED LEARNING OUTCOMES IN SAUDI HIGHER EDUCATION}

Omaymah Radwan, Ahmad Zabidi Bin Abdul Razak (PhD), \& Simin

Ghavifekr (PhD)

\begin{abstract}
The current study aims to analyse the direct and significant effect of academic leadership skills on students' skill-based learning outcomes in selected higher education institution in the Kingdom of Saudi Arabia (KSA). It also aims to analyse the mediating effect of organisational culture on academic leadership skills and students' skill-based learning outcomes. The study was conducted with a quantitative research methodology by distributing questionnaires contained 97 items to faculty members in Jazan University, Saudi higher education institution. A total of 350 responses were further analysed using the SPSS (V23) and PLSSEM. Results indicated that academic leadership skills have no direct and significant effect on students' skill-based learning outcomes in selected higher education institution in the KSA. Results also indicated that organisational culture has a significant mediation effect on academic leadership skills and student's skill-based learning outcomes in selected higher education institution in the KSA. The present study has the potential to reflect positively on higher education, academic leadership, as well as students in higher education.
\end{abstract}

Keywords: Academic Leadership Skills, Organisational Culture, Skill-Based Learning Outcomes, Higher Education, Saudi Arabia. 


\section{MALAYSIAN ONLINE JOURNAL OF EDUCATIONAL MANAGEMENT (MOJEM)}

\section{INTRODUCTION}

Higher education institutions play an essential role in increasing social and economic growth (Amanchukwu, Stanley, \& Ololube, 2015; Deore \& Ratnalikar, 2010). The output of higher education institutions is vital for achieving success in any society. They are responsible for preparing qualified individuals with different specialties to meet the needs of the community (Altalhi, 2012). Therefore, higher education needs a competent and skilled academic leadership that provide help to achieve quality education and contribute to the nation's improvement (Albutti, 2014; Altalhi, 2012). Academic leadership in higher education affects students learning outcomes (Shahmandi, Silong, \& Ismail, 2012). A number of studies also have pointed out that leadership has an effect and relationship with improving the performance, students' achievements, and students' learning outcomes (Al-Safran, Brown, \& Wiseman, 2014; Balwant, 2016; Day, Gu, \& Sammons, 2016; Harrison, 2011; Pina, Cabral, \& Alves, 2015; Robinson, Lloyd, \& Rowe, 2008).

Al-Safran et al. (2014) stated that leadership has directly and indirectly impacted students' learning outcomes. Leadership skills and leadership style can affect the outcome of students. Transformational leadership, for instance, empowers the lecturers through professional training, better wages, and flexible working hours, and then indirectly impact the students' outcomes (Al-Safran et al., 2014; Day et al., 2016; Robinson et al., 2008). Besides, academic leaders who need to improve their leadership skills need to assess leadership behaviours using Multifactor Leadership Questionnaire MLQ (Bass \& Avolio, 1994). The MLQ focused on transformational and transactional leadership behaviours. The previous studies clarified that the transformational and transactional leadership are the most useful skills that impacted on students learning outcomes (Al-Safran et al., 2014; Balwant, 2016; Day et al., 2016; Harrison, 2011; Pina et al., 2015; Robinson et al., 2008).

In order for leaders to impact positively on students' learning outcome, they have to consider mediate elements (Alfraih, 2014; Bell, Bolam, \& Cubillo, 2003; Leithwood \& Jantzi, 2000). Academic leaders can indirectly impact on students learning outcomes by utilising effective mediating components in their environment. Organisational culture is considered one of the useful elements that have an impact on students and institutions' outcomes (Alsarahani, 2012; Alshibani \& Alatwi, 2011). Accordingly, academic leaders must be aware of the critical role of organisational culture that provides solutions for different needs in their institutions (Alshibani \& Alatwi, 2011; Imam, Abbasi, Muneer, \& Qadri, 2013). Organisational culture is defined as a group of norms, values, rules, beliefs, habits, and principles, that exist among organisation's members and influenced their behaviours, feelings, attitudes, thoughts, and decisions (Alsarahani, 2012; Imam et al., 2013). It affects the organisation's development (Sheikhalizadeh \& Piralaiy, 2017). It has a relation to the performance of higher education institutions (Imam et al., 2013). It has a substantial role in changing and improving colleges and universities. Studies pointed out that it has a remarkable role in helping academic leaders to increase the students' learning outcomes (Fralinger \& Olson, 2007).

The Kingdom of Saudi Arabia (KSA) is one of the countries that paid more attention for reforming education and achieving global quality standards in its system (Alshayea, 2012; Saudi Ministry of Education, 2019). It has made remarkable efforts for encouraging students to study abroad by offering them full scholarships. The number of Saudi's higher education students who are studying abroad under scholarships has risen to more than 114,000 students in 2017 (Alshayea, 2012; Saudi Ministry of Education, 2019). Therefore, Saudi government gives more consideration to the improvement of educational leaders and students to achieve the desired outcomes of the society (Saudi Ministry of Education, 2019). In line with that, it pays more consideration to the organisational culture that builds the university's principles (Alsarahani, 2012). Organisational culture in Saudi higher education is the most significant pillar in building its principles (Alsarahani, 2012). It enhances academic productivity and increases their motives. The Saudi Ministry of Education is working on reforming and transforming higher education by improving the administrative and leadership environment and increasing the students' learning outcomes (Saudi Ministry of Education, 2019). This movement will not be completed without consideration of 


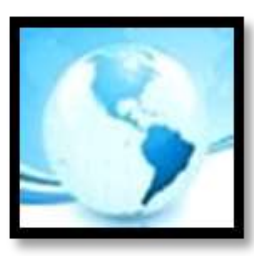

\section{MALAYSIAN ONLINE JOURNAL OF EDUCATIONAL MANAGEMENT (MOJEM)}

organisational culture, because it is the corner-stone of building higher education's principles and causing the improvement of the performance (Alsarahani, 2012).

The previous studies clarified that leadership can impact indirectly on students learning outcomes (Al-Safran et al., 2014; Balwant, 2016; Day et al., 2016; Harrison, 2011; Pina et al., 2015; Robinson et al., 2008). They also clarified that leaders must consider mediating components that may help them to reach the desired outcomes (Bell et al., 2003; Leithwood \& Jantzi, 2000). Organisational culture is one of the significant components that lead to improvement of the outcomes and performance in higher education (Alsarahani, 2012; Sheikhalizadeh \& Piralaiy, 2017). However, most of these studies were conducted in the schools' environment regardless of higher education institutions. To date, there is still a lack of studies that focused on the mediating effect of organisational culture on academic leadership skills and students learning outcomes in term of their skills-based learning outcomes in higher education. While a number of studies analyse the impact of leadership on students learning outcomes, there were others that focused on examining the mediation effect of organisational culture in educational environment. The current study connected these three variables and concentrate on the effect of leadership skills (transformational and transactional leadership) on students' skill-based learning outcomes via organisational culture as a mediator. Therefore, the current study aimed to examine the mediating effect of organisational culture on academic leadership skills and students' skill-based learning outcomes in selected higher education institution in the KSA. As such, this study aimed to answer the following questions:

1. Do academic leadership skills have a direct and significant effect on students' skill-based learning outcomes in selected higher education institution in the KSA?

2. Is organisational culture a mediator which has a significant mediation effect on academic leadership skills and students' skill-based learning outcomes in selected higher education institution in the KSA?

Figure 1 below presents the conceptual framework of the study that clarified the relationship between study's variables:

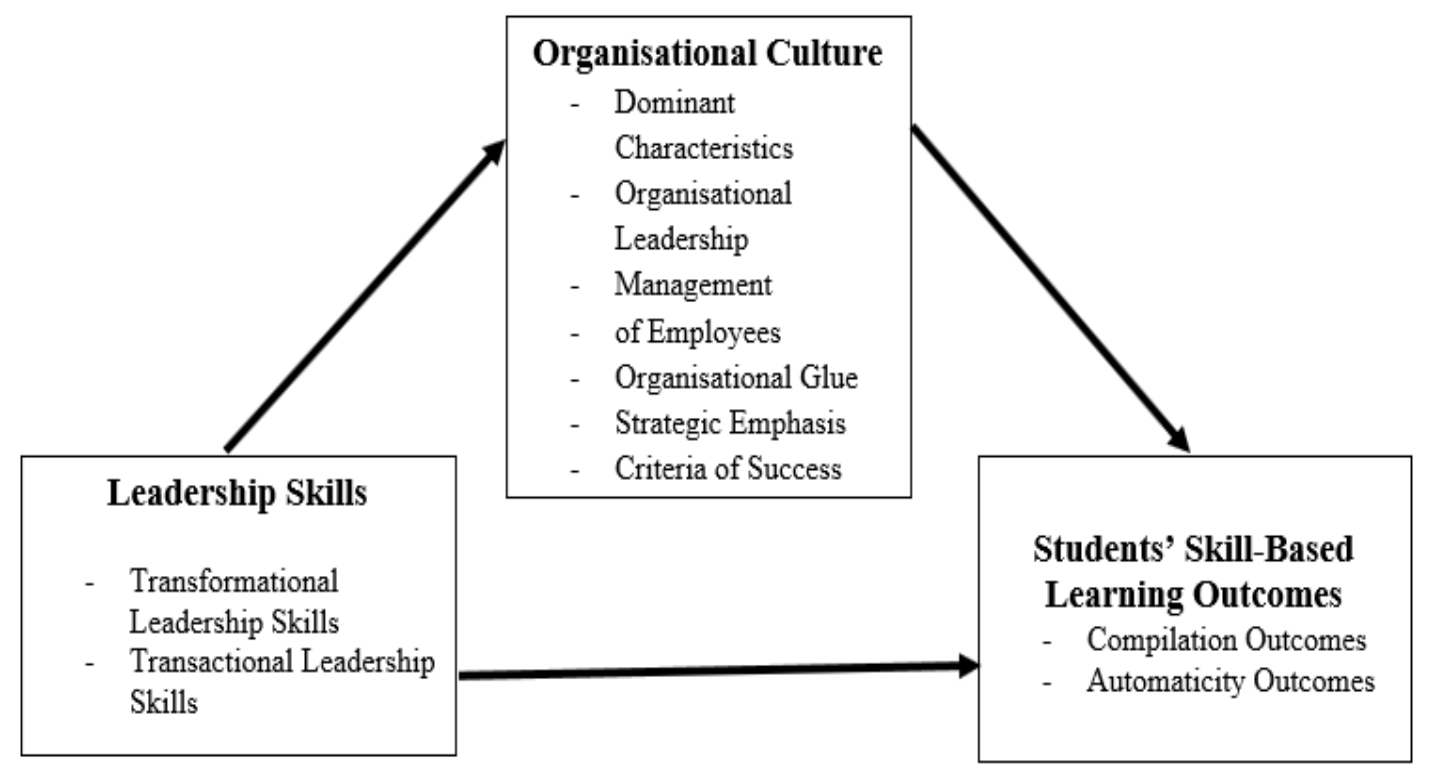

Figure 1. Conceptual Framework (Source: Bass \& Avolio, 1994; Bell et al., 2003; Cameron \& Quinn, 2011; Kraiger et al., 1993; Leithwood \& Jantzi, 2000; Northouse, 2016) 


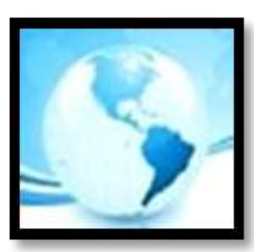

\section{MALAYSIAN ONLINE JOURNAL OF EDUCATIONAL MANAGEMENT (MOJEM)}

The diagram above presented that the exogenous variable leadership skills of academic leaders focused on two skills transformational leadership and transactional leadership skills (Bass \& Avolio, 1994). It also displayed that organisational culture plays a mediation role and has six dimensions: dominant characteristics, organisational leadership, management of employees, organisational glue, strategic emphasis, and criteria of success (Cameron \& Quinn, 2011). The endogenous variable focused on students' skills-based learning outcomes that cover compilation and automaticity outcomes (Kraiger, Ford, \& Salas, 1993). According to the conceptual framework and discussion above, the study aimed to analyse the mediating effect of organisational culture on academic leadership skills and student's skill-based learning outcomes in selected higher education institution in the KSA. In order to achieve this aim and answer research questions, 2 null hypotheses have been formulated as follow:

$\mathrm{H}_{\circ 1}$ : there is no direct and significant effect of leadership skills on students' skills-based learning outcomes in selected higher education institution in the KSA.

$\mathrm{H}_{\mathrm{o2}}$ : organisational culture is not a mediator that plays a significant effect on leadership skills of academic leaders and students' skills-based learning outcomes in selected higher education institution in the KSA.

\section{THEORETICAL FOUNDATION}

Four main theories and theoretical models have been used in the current study. These selected theories were transformational and transactional leadership (Bass \& Avolio, 1994), organisational culture assessment instrument (OCAI) for Cameron and Quinn (2011), and the Classification Scheme of Learning Outcomes for Kraiger, Ford and Salas (1993).

Transformational leadership approach focused on developing and improving followers' performance (Bass \& Avolio, 1994; Northouse, 2016). It helps to transform and change individuals. It focuses on values, emotions, ethics, standards, and long-term goals. It inspires individuals to do more work than what is expected of them to do. It helps leaders to exceed their interest for the good of the followers and organisation (Bass \& Avolio, 1994). This kind of leadership has shown to be useful in diverse situations (Mutahar, Rasli, \& Al-Ghazali, 2015; Northouse, 2016; Yukl, 2013). It makes followers feel more confident about themselves. It is a very effective and successful form of leadership. It is valuable and worthy leadership skill that is widely used (Yukl, 2013). It has different factors, namely; idealised influence, inspirational motivation, intellectual stimulation, and individualised consideration.

Transactional leadership has another definition called Managerial Leadership. Burns clarified that transactional leadership indicates to leadership models that emphasis on the exchange between leaders and followers (Northouse, 2016). Leaders in transactional leadership do not focus on followers' needs and personal development (Bass \& Avolio, 1994; Northouse, 2016). They concentrate on exchange things with their followers. The exchange feature is prevalent in transactional leadership. Contingent Rewards and Management-by-Exception are two different factors related to transactional leadership (Bass \& Avolio, 1994; Northouse, 2016). Contingent rewards refer to the exchange process between leader and followers. Followers have to do what leaders ask them to do and then get rewards from their leaders. Leaders, in management by exception, focused on negative feedback and reinforcement, and corrective criticism, (Bass \& Avolio, 1994; Northouse, 2016). Leaders, in management by exception follow two forms: active and passive. The active form used to watch followers closely for making mistakes and taking immediate corrective action. The passive form used when the leaders wait until the problems appear or when the followers did not do what expected of them to do.

Both skills' transformational and transactional leadership have positive and direct effects on the individuals and the organisation's performance (Long \& Mao, 2008; Yang \& Wei, 2009). Yang and Wei (2009) examined the relationship between transformational and transactional leadership and the performance and capability of the organisational innovation. The findings of this study indicated that transformational and transactional leadership have a positive impact on the performance of the organisation's innovation. Likewise, a study conducted by Long and Mao (2008) to analyse the impact of leadership on achieving the required change in the organisation. The 


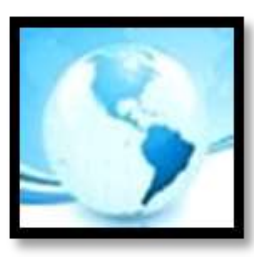

\section{MALAYSIAN ONLINE JOURNAL OF EDUCATIONAL MANAGEMENT (MOJEM)}

findings indicated that transformational and transactional leadership have a positive effect on organisational change. Accordingly, both transformational and transactional leadership have a positive impact on the individuals and organisation.

To measure the culture within organization, a number of models, instruments, and measurements were developed. The present study used the OCAI to measure culture within higher education sector, because it considered as the most suitable instrument for studying culture in higher education (Alshibani \& Alatwi, 2011; Vasyakin, Ivleva, Pozharskaya, \& Shcherbakova, 2016). The OCAl developed by Cameron and Quinn (2011) to evaluate six dimensions in an organisation, namely dominant characteristics, organisational leadership, management of employees, organisational glue, strategic emphasis, and criteria of success. Each dimension has four alternative items that exemplify four types of culture, including Clan Culture, Adhocracy Culture, Market Culture, and Hierarchy Culture. In each dimension, 100 points must be divided among these items. The highest number should be given to the item that is more related to the organisation. Each item also can be rated based on 1 to 5 or 1 to 7 Likert-scale. Both techniques can be applied based on the nature and the objectives of the study (Cameron, \& Quinn, 2011; Quinn \& Spreitzer, 1991; Yeung, Brockbank, \& Ulrich, 1991). The current study adopted the OCAI for Cameron and Quinn (2011) to examine the organisational culture in the context of Saudi higher education.

To measure learning outcomes of individuals, one can apply the Classification Scheme of Learning Outcomes for Kraiger et al. (1993). This theoretical model was developed to evaluate the learning outcomes including cognitive outcomes, skill-based outcomes, and affective outcomes. All these learning outcomes cover different measurements. Cognitive outcomes involve cognitive strategies, verbal knowledge, and knowledge organisation. Skill-based learning outcomes include compilation outcomes and automaticity outcomes. The affective outcomes comprise attitudinal outcome and motivational outcomes. To conclude, the current study focused on skill-based learning outcomes in higher education students.

\section{Academic Leadership Skills and Students' Skill-Based Learning Outcomes in Higher Education}

Both leadership and students' outcomes are very crucial in higher education. Gabbard (2017) stated that faculty members and academic leaders in higher education must invest more energy to develop students learning. To date, there is no meta-analysis that focused on the effect of academic leadership on students learning outcomes in higher education (Shahmandi et al., 2012; Southwell \& Morgan, 2009). Minimal studies pointed out that leadership affects students learning outcomes at higher education (Shahmandi et al., 2012). These studies pointed out that leadership has a direct and indirect effect on students' outcomes, their achievements, and the institutions' performance (Al-Safran et al., 2014; Balwant, 2016; Day et al., 2016; Harrison, 2011; Pina et al., 2015; Robinson et al., 2008). Most of the previous literature studied this issue from different angles and focused on general schools regardless of higher education.

Likewise, Bell et al. (2003) conducted a systematic review to examine the impact of leadership on students learning outcomes in general education. They found that school leaders have an indirect effect on students' outcomes. Similarly, Leithwood, Louis, Anderson, and Wahlstrom (2004) also examined different research studies regarding the relationship between school leadership and students learning outcomes. They found that leadership has direct and indirect effect students learning. Besides, Leithwood and Jantzi (2008) indicated from their study that there is indirect effect of leadership on students learning. Southwell and Morgan (2009) stated that the impact of leadership on students' outcomes is complicated and not easy to measure. Leithwood, Louis, Wahlstrom, Anderson, Mascall, and Gordon (2010) examined the relationship between school leadership and students learning at 130 American schools. They found that school leaders have a small effect on students learning and this effect is indirect. Leithwood, Patten and Jantzi (2010) examined how school leadership impact on students' learning. They found an indirect relationship between school leadership and students' learning. Likewise, Sebastian and Allensworth (2012) conducted a study to find out the impact of school leaders on students learning outcomes. 


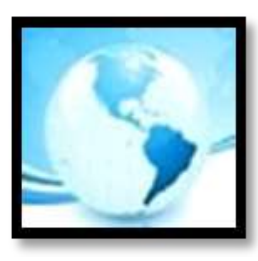

\section{MALAYSIAN ONLINE JOURNAL OF EDUCATIONAL MANAGEMENT (MOJEM)}

They found that when school leaders shift their attention to developing the learning environment and support teachers to improve their career, that leads to a high level of job satisfaction among staff. Hence, they pointed out that school leaders impact directly on teachers and indirectly on students learning outcomes.

Similarly, Pina et al. (2015) conducted a study on six schools in Portugal to examine the impact of school leadership on students' outcomes. They concluded that leaders could impact indirectly on student outcomes. They also clarified that school leaders how to apply transformational leadership could impact directly on teachers by enhancing their work and give them the necessary support, and then impact indirectly on students' outcomes. Barker (2007) also conducted a study on school leadership and students' outcomes. His study found that transformational leadership has no clear impact on student outcomes. Alfraih (2014) did a study to examine how transformational leadership affects the students' outcomes in 86 public schools in Kuwait. His study indicated that transformational leadership, directly and indirectly, affect the students' outcomes. Al-Safran et al. (2014) conducted a study to determine how various school leadership and administrative styles affect students' academic and non-academic performance. They found that transformational leadership has little effect on students' performance but is more influential on the teacher's attitudes. Day et al. (2016) conducted a study to examine the impact of school leaders on students' outcomes. The researchers examined how school leaders apply different leadership strategies in their work. They found that successful school leaders, directly and indirectly, contribute to improving the schools and students' outcomes through combining different skills of leadership including transformational leadership in their work.

\section{The Mediation Role of Organisational Culture on Academic Leadership Skills and Students' Skill-Based Learning Outcomes in Higher Education}

Organisational culture is a very crucial component in higher education. It indicates to a set of behaviours, values, attitudes, thoughts, and rules that run from the head to the line managers who can spread the culture between the individuals in the organisation (Li, Bhutto, Nasiri, Shaikh, \& Samo, 2018). It has a significant role for academic leaders who can apply it to solve many problems regarding the educational environment (Tierney, 1988). Previous studies pointed out that there is a strong relationship between leadership, organisational culture and the organisation outcomes. Both leadership and organisational culture have a positive effect on the organisation's performance.

Besides, transformational leadership and transactional leadership are significant for organisation effectiveness (Bass \& Avolio, 1994). Acquiring transformational and transactional qualities by leaders allow them to achieve improvement in the organisation (Bennett \& Valdes, 2006; Northouse, 2016). Both leaderships enable academic leaders to improve their skills and become effective leaders who cause the required development in the institutes. Leithwood and Jantzi (2000) clarified that although transformational leadership has a significant impact on the organisation's performance and outcomes, its impact on students 'outcomes is weak. In order for transformational leadership to effect on students, it must study with the existing mediator's element that allows leaders to impact positively on students' outcomes. They pointed out that organisational culture is one of the mediating elements that leaders can utilise to impact on students positively. Besides, Ogbonna and Harris (2000) studied the mediating role of organisational culture on leadership style and the organisation's performance. They concluded that the organisational culture mediates the relationship between leadership style and the organisation's performance.

Similarly, Li et al. (2018) conducted a study to analyse the mediating effect of organisational culture on the relationship between leadership and organisational innovation. They focused on examining whether organisational culture mediates transactional leadership, transformational leadership, and the innovation of different universities in the world. Li et al. (2018) found out that organisational culture plays a mediation role between these variables in higher education institutions. Therefore, the previous studies pointed out that there is no direct effect of leadership on student's learning outcome. They also clarified that organisational culture plays a significant mediate role in higher education. 


\section{METHOD}

\section{Research Design, Population and Sampling}

The current study utilised a quantitative research methodology that focused on survey design. The data collected from faculty members worked in Jazan University, Jazan Province, which located in the southern region of the KSA. This university has a large number of faculty members, staff and students who share similar features with others in other universities around the KSA (Saudi Ministry of Education, 2019). The questionnaires were distributed using a random sampling technique. According to Creswell (2012), random sampling technique allows generalisation to occur on the population. The total number of faculty members at Jazan University was 3431. According to Chua (2016), the minimum sample size suggested for a total number of 3500 is 346 respondents based on the recommended table by Krejcie and Morgan's (1970). Besides, Creswell (2018) recommended that one must collect a higher number of respondents to avoid any problem in data analysis. Based on that, the researchers collected more than 346 respondents.

\section{Instrumentation}

The current study utilised questionnaire adopted from several instruments and contained 97 items. It included four core parts; namely, demographic information, leadership skills, the organisational culture, and the students' skill-based learning outcomes. The demographic information section covered the respondents' gender, age, experience, and qualification. The leadership skills contain 16 items adopted from MLQ for (Bass \& Avolio, 1994), the organisational culture contain 71 items adapted from the OCAl for Cameron and Quinn (2011). The students' skill-based learning outcomes include 10 items and adapted from the Classification Scheme of Learning Outcomes for Kraiger et al. (1993). Besides, the researchers applied the 5-point Likert scale to analyse the respondents' opinion, according to ( $1=$ Strongly Disagree, 2= Disagree, 3= Neutral, 4= Agree, and 5= Strongly Agree). In brief, the questionnaire was developed on a 5-point Likert scale and contained 97 items.

To assess the validation and reliability of the instrument, the questionnaire was pilot-tested at a higher education with 150 responses. The validation and reliability were tested using structural equation modelling PLS-SEM (See Figure 2). The following sections included more details regarding the validation and reliability of the instrument. In addition, Figure 2 below presents the assessment of measurement model that cover the validity and reliability of the instrument. 


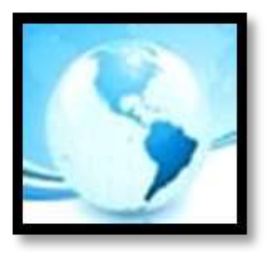

MALAYSIAN ONLINE JOURNAL OF

EDUCATIONAL MANAGEMENT

(MOJEM)

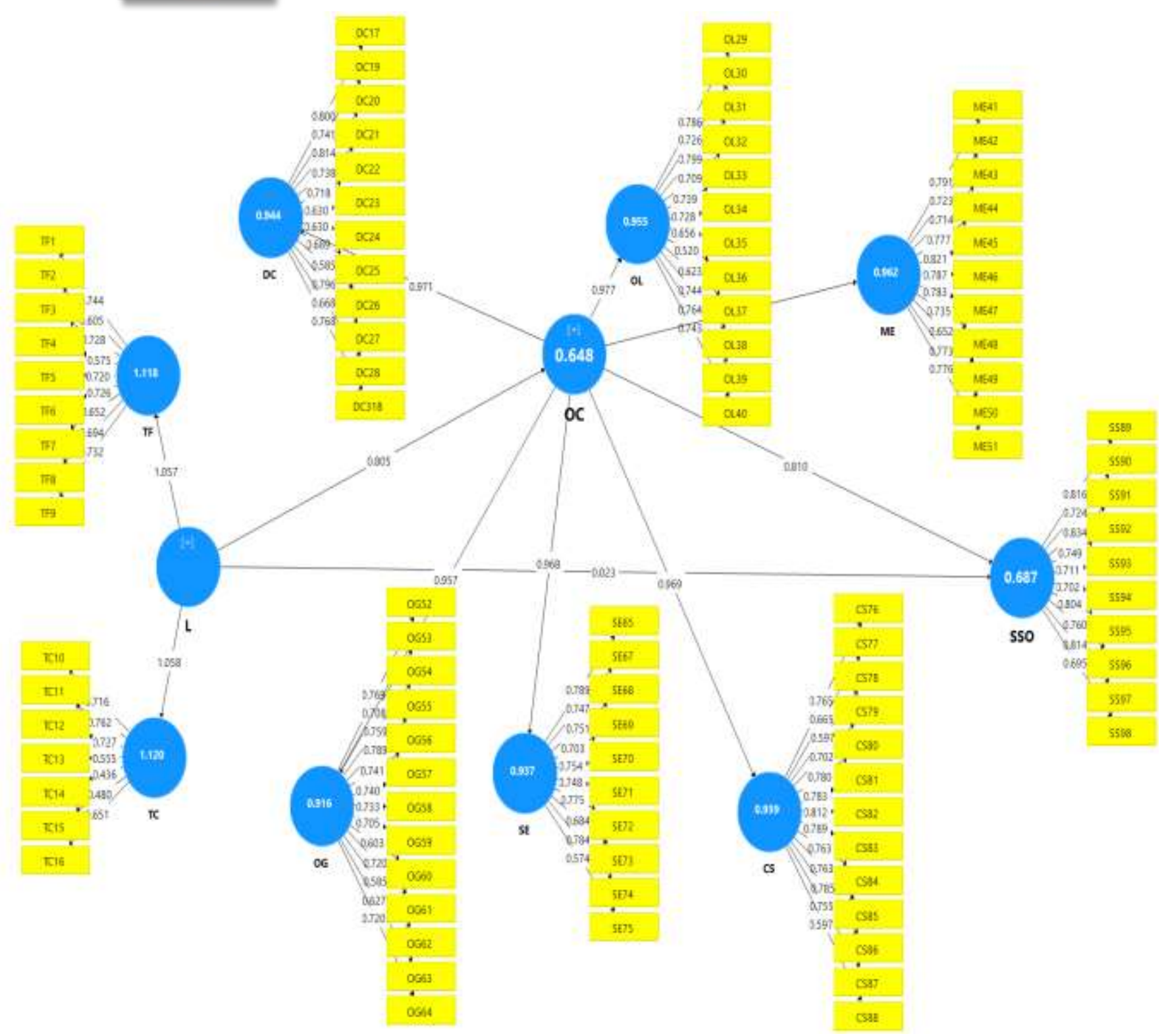

Figure 2. Measurement Model Assessment

\section{Validation}

The validation was conducted by face, convergent and discriminant validity. Four different experts in the filed have completed the face validating. Through PLS-SEM, the convergent and discriminant validity were tested. The convergent validity was done through checking the values of Average Variance Extracted (AVE) and factor loading (see Figure 2). The AVE refers to the correlation between the constructs (Hair, Hult, Ringle, \& Sarstedt, 2017). The value of 0.5 and above indicates a high level of validity. Accordingly, the findings in Table 1 below demonstrated that all values of the AVE were within the acceptable range of the convergent validity. 


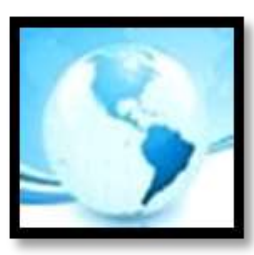

MALAYSIAN ONLINE JOURNAL OF

EDUCATIONAL MANAGEMENT

(MOJEM)

Table 1

Results of AVE

\begin{tabular}{llc}
\hline Variable & & Average Variance Extracted (AVE) \\
\hline L & TF & 0.532 \\
& TC & 0.506 \\
\hline OC & DC & 0.516 \\
& OL & 0.512 \\
& ME & 0.576 \\
& OG & 0.505 \\
& SE & 0.538 \\
& CS & 0.545 \\
\hline SO & SSO & 0.582 \\
\hline
\end{tabular}

Key: L= Leadership Skills; TF= Transformational Leadership; TC= Transactional Leadership; OC= Organisation Culture; $\mathrm{DC}=$ Dominant Characteristics; $\mathrm{OL}=$ Organisational Leadership; $\mathrm{ME}=$ Management of Employees; $\mathrm{OG}=$ Organisation Glue; SE= Strategic Emphases; $C S=$ Criteria of Success; SO=Students Outcomes; SSO= Students Skill Outcomes

The factor loading presented in Figure 2 also indicated that all the items loaded with an acceptable range of 0.5 and above (Hair et al., 2017). In addition, the discriminant validity implies to the degree in which a construct is dissimilar from other constructs (Hair et al., 2017). It tested through Fornell-Larcker Criterion, and Heterotraitmonotrait ratio (HTMT). Table 2 and Table 3 show the results of the discriminant validity.

Table 2

The results of Fornell-Larcker criterion

\begin{tabular}{|c|c|c|c|c|c|c|c|c|c|c|c|}
\hline & CS & DC & $\mathbf{L}$ & ME & OC & OG & $\mathrm{OL}$ & SE & SSO & TC & TF \\
\hline CS & 0.738 & & & & & & & & & & \\
\hline DC & 0.862 & 0.718 & & & & & & & & & \\
\hline $\mathbf{L}$ & 0.774 & 0.796 & 0.647 & & & & & & & & \\
\hline ME & 0.891 & 0.936 & 0.768 & 0.759 & & & & & & & \\
\hline OC & 0.969 & 0.971 & 0.805 & 0.981 & 0.697 & & & & & & \\
\hline OG & 0.893 & 0.899 & 0.727 & 0.893 & 0.957 & 0.71 & & & & & \\
\hline OL & 0.898 & 0.935 & 0.815 & 0.935 & 0.977 & 0.865 & 0.715 & & & & \\
\hline SE & 0.944 & 0.872 & 0.736 & 0.912 & 0.968 & 0.864 & 0.902 & 0.733 & & & \\
\hline SSO & 0.803 & 0.783 & 0.675 & 0.808 & 0.828 & 0.744 & 0.804 & 0.815 & 0.763 & & \\
\hline TC & 0.809 & 0.838 & 1.058 & 0.799 & 0.839 & 0.74 & 0.844 & 0.783 & 0.721 & 0.629 & \\
\hline TF & 0.716 & 0.729 & 1.057 & 0.712 & 0.746 & 0.687 & 0.758 & 0.67 & 0.609 & 0.912 & 0.689 \\
\hline
\end{tabular}

The findings from the table above indicated that the discriminate validity could not establish under Fornell-Larcker Criterion. Therefore, the values of HTMT has been tested as suggested by Henseler, Ringle, and Sarstedt (2015). The standard of HTMT value is normed between 0 to 1 . The problem in the discriminant validity accrued if the values of HTMT are higher than 1 (Alarcón, Sánchez, \& De Olavide, 2015; Henseler et al., 2015). Therefore, after testing the HTMT, the results indicated that the discriminant validity could establish under the HTMT. Table 3 below shows the results of HTMT. 


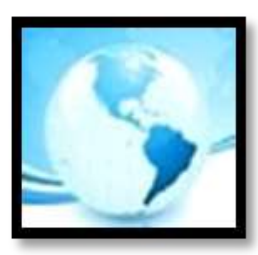

(MOJEM)

Table 3

Results of the HTMT

\begin{tabular}{llllllllllll}
\hline & CS & DC & L & ME & OC & OG & OL & SE & SSO & TC & TF \\
\hline CS & & & & & & & & & & & \\
DC & $\mathbf{0 . 8 6 3}$ & & & & & & & & & & \\
L & 0.78 & $\mathbf{0 . 8 0 2}$ & & & & & & & & & \\
ME & 0.892 & 0.936 & $\mathbf{0 . 7 7 3}$ & & & & & & & & \\
OC & 0.97 & 0.973 & 0.811 & $\mathbf{0 . 9 8}$ & & & & & & & \\
OG & 0.895 & 0.903 & 0.734 & 0.894 & $\mathbf{0 . 9 6 1}$ & & & & & & \\
OL & 0.903 & 0.938 & 0.826 & 0.939 & 0.98 & $\mathbf{0 . 8 7}$ & & & & & \\
SE & 0.945 & 0.873 & 0.741 & 0.912 & 0.968 & 0.866 & $\mathbf{0 . 9 0 4}$ & & & & \\
SSO & 0.806 & 0.78 & 0.681 & 0.807 & 0.828 & 0.746 & 0.809 & $\mathbf{0 . 8 1 3}$ & & & \\
TC & 0.804 & 0.841 & 1.051 & 0.799 & 0.839 & 0.74 & 0.852 & 0.785 & $\mathbf{0 . 7 3 4}$ & & \\
TF & 0.718 & 0.728 & 1.055 & 0.71 & 0.744 & 0.687 & 0.76 & 0.667 & 0.604 & $\mathbf{0 . 8 7 2}$ & \\
\hline
\end{tabular}

Based on the discussion above, the values of HTMT were acceptable, according to Alarcón et al. (2015) and Henseler et al. (2015). Therefore, discriminant validity could establish under HTMT.

\section{Reliability}

Reliability test was checked via PLS-SEM and included testing the composite reliability (CR) and Cronbach's alpha. The acceptable values of CR and Cronbach's Alpha range between 0.70 and 0.95 (Hair et al., 2017; Pallant, 2013). The findings of Table 4 below show the results of the reliability test.

Table 4

Results of Reliability Test

\begin{tabular}{|c|c|c|c|c|}
\hline \multicolumn{2}{|c|}{ Variable } & \multirow{2}{*}{$\begin{array}{c}\text { Cronbach's Alpha } \\
0.931\end{array}$} & \multirow{2}{*}{$\begin{array}{c}\text { Composite Reliability (CR) } \\
0.920\end{array}$} & \multirow{2}{*}{$\begin{array}{c}\text { AVE } \\
0.532\end{array}$} \\
\hline $\mathbf{L}$ & TF & & & \\
\hline & TC & 0.902 & 0.918 & 0.506 \\
\hline \multirow[t]{6}{*}{ OC } & DC & 0.926 & 0.927 & 0.516 \\
\hline & OL & 0.924 & 0.926 & 0.512 \\
\hline & ME & 0.937 & 0.937 & 0.576 \\
\hline & OG & 0.928 & 0.929 & 0.505 \\
\hline & SE & 0.920 & 0.920 & 0.538 \\
\hline & CS & 0.938 & 0.939 & 0.545 \\
\hline so & SSO & 0.933 & 0.933 & 0.582 \\
\hline
\end{tabular}

Based on the discussion and the results of the tables above, the values of the CR, Cronbach's Alpha, and the AVE were within the acceptable range. Therefore, the current instrument is a valid and reliable instrument that can be used to collect and analyse data.

\section{RESULTS}

The data was collected after testing the validity and reliability of the instrument. The data were collected from faculty members working at Jazan University. A total of 420 responses was received to avoid any problem in data analysis as suggested by Creswell (2018). After data screening, including checking the missing data and the outliers, 


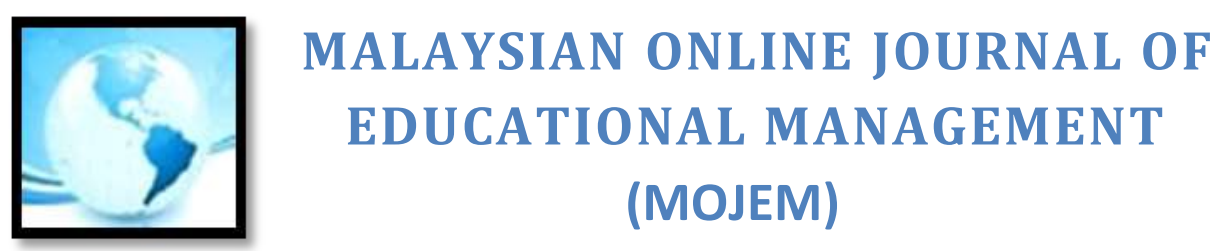

only 350 responses were found to be ready for analysis. The number of 350 responses was the target of this study as stated earlier. Hence, the data were analysed based on the 350 responses using SPSS (V.23) and PLS-SEM. The findings of this analysis included the demographic information, and the findings of hypotheses testing.

\section{Demographic Information of the Respondents}

Descriptive analysis has been conducted via SPSS to analysis the demographic information of the respondents. Table 5 below presents these details.

Table 5

Demographic Information of the Respondents

\begin{tabular}{llll}
\hline Item & & $\mathbf{N}$ & $\mathbf{\%}$ \\
\hline Gender & Male & 163 & 47.1 \\
& Female & 183 & 52.9 \\
\hline Age & $20-30$ & 75 & 21.7 \\
& $31-40$ & 176 & 50.9 \\
& $41-50$ & 73 & 21.1 \\
\hline Experiences & 51 and above & 22 & 6.4 \\
& Less than 5 years & 137 & 39.6 \\
& From 6-10 years & 114 & 32.9 \\
& From 11-15 years & 49 & 14.2 \\
\hline Qualification & Over 15 years & 46 & 13.3 \\
& Diploma & 4 & 1.2 \\
& Bachelor & 42 & 12.1 \\
& Master & 217 & 62.7 \\
& PHD/EDD & 83 & 24.0 \\
\hline
\end{tabular}

Table 5 above showed that female respondents of 183 (52.9\%) were higher than that of males 163(47.1\%). The majority of respondents of $176(50.9 \%)$ were between 31 to 40 years old. A large number of respondents of 137 (39.9\%) had working experience between five years and less. Finally, the majority of respondents of 217 (62.7\%) were holding a master degree.

\section{Hypotheses Testing}

Two null hypotheses have been formulated to answer research questions. The null hypotheses tested based on the values of path coefficient $(\beta)$ (between -1 and +1 ), T-value $(>1.96)$, and the $p$-value $(<0.05)$. The null hypothesis should be rejected if the $p$-value is equal or $<0.05$. In contrast, the null hypothesis must be accepted if the $p$-value is higher than 0.05 (Fraenkel, Wallen, \& Hyun, 2015; Hair, Black, Babin, \& Anderson, 2014). Figure 3 below presented the structural model assessment (hypotheses model). 


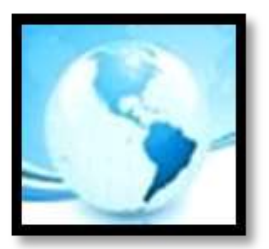

MALAYSIAN ONLINE JOURNAL OF

EDUCATIONAL MANAGEMENT

(MOJEM)

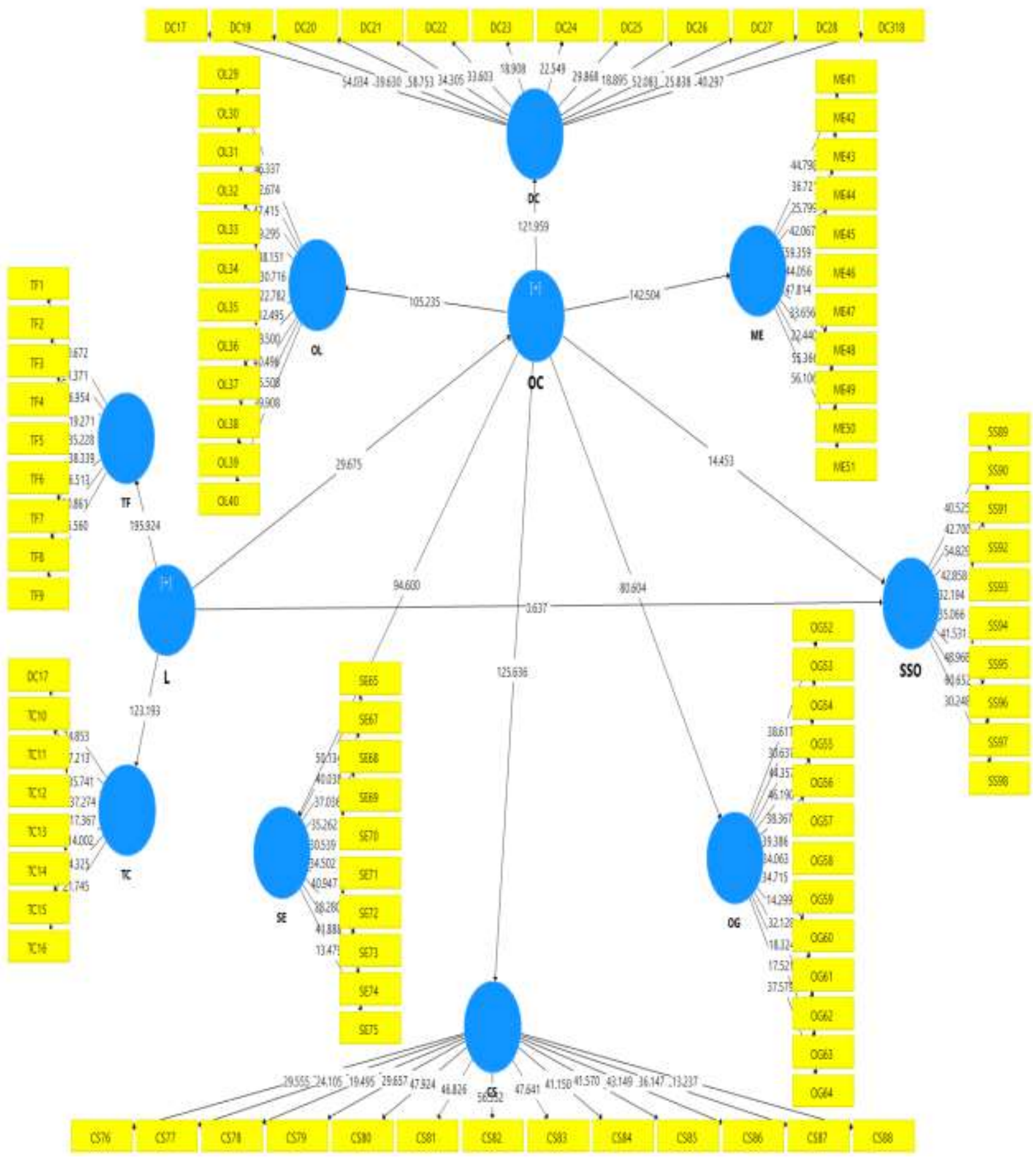

Figure 3. The structural model assessment (Hypotheses Model) 


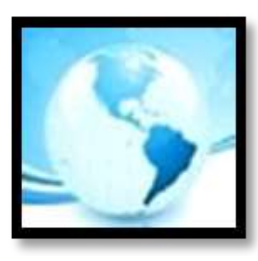

\section{MALAYSIAN ONLINE JOURNAL OF EDUCATIONAL MANAGEMENT (MOJEM)}

The following sections included more details regarding hypotheses testing and answering research questions based on the results of path coefficient $(\beta), T$-value, and the $p$-value.

\section{Academic Leadership Skills and Students' Skill-Based Learning Outcomes}

This section provides answer for research question 1 that focused on analysing the effect of academic leadership skills and students' skill-based learning outcomes. To answered this question, null hypothesis ( $H_{\circ 1)}$ has been formulated and tested as follow:

$\mathrm{H}_{\circ 1}$ : There is no direct and significant effect of leadership skills on students' skills-based learning outcomes in selected higher education institution in the KSA.

Table 6 below presents the findings of $\mathrm{H}_{\circ 1}$.

Table 6

The Results of Hypotheses Testing $\left(\mathbf{H}_{\mathbf{0}}\right)$

\begin{tabular}{|c|c|c|c|c|c|c|}
\hline $\mathrm{H}$ & & $\begin{array}{l}\text { PATH COEFIICIENT } \\
(\beta)\end{array}$ & $\begin{array}{l}\text { T-Value } \\
(>1.96)\end{array}$ & $\begin{array}{l}\text { P Value } \\
(<0.05)\end{array}$ & $\mathbf{R}^{2}$ & Decision \\
\hline $\mathrm{H}_{01}$ & $\begin{array}{l}\mathrm{L}->\text { SSO } \\
\text { No direct and } \\
\text { significant effect of } \mathrm{L} \\
\text { on SSO }\end{array}$ & 0.04 & 0.621 & $0.535^{* *}$ & 0.687 & $\begin{array}{l}\text { Supported } \\
\text { (Accepted) }\end{array}$ \\
\hline
\end{tabular}

Note: Significance level $* * p<0.05$

Key: L= Leadership Skills; SSO= students' skill-based learning outcomes

Table 6 above showed the findings of hypothesis testing $\mathbf{H}_{\mathbf{o} 1}$. The findings have failed to reject the null hypothesis $H_{\circ 1}$. The results of the effect of leadership skills on students' skill-based learning outcomes were $(\beta=0.04, t=0.621$, $p>0.05)$. The $\beta$ value indicated no relationship between the constructs, the t-value was below than 1.96 , and the $p-$ value was not significant. Thus, the null hypothesis $\left(\mathrm{H}_{\circ 1}\right)$ has been accepted. Thus, the results answered research question 1 and indicated that there is no direct and significant effect of leadership skills on students' skill-based learning outcomes in selected higher education institution in the KSA.

The Mediation Effect of Organisational Culture on Leadership Skills of Academic Leaders and Students' SkillBased Learning Outcomes

This section provides answer for research question 2 that focused on analysing the mediation effect of organisational culture on leadership skills of academic leaders and students' skill-based learning outcomes. To answer this question, null hypothesis $\mathrm{H}_{\circ 2}$ has been formulated and tested as follow:

$\mathrm{H}_{\mathrm{o} 2}$ : organisational culture is not a mediator that plays a significant effect on leadership skills of academic leaders and students' skills-based learning outcomes in selected higher education institution in the KSA. Table 7 below presented more details regarding the hypothesis testing $\mathrm{H}_{\circ 2}$. 


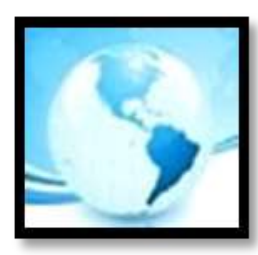

MALAYSIAN ONLINE JOURNAL OF

EDUCATIONAL MANAGEMENT

(MOJEM)

Table 7

The Results of Hypotheses Testing $\left(\mathrm{H}_{\mathrm{o} 2}\right)$

\begin{tabular}{|c|c|c|c|c|c|c|}
\hline $\mathbf{H}$ & & $\begin{array}{c}\text { PATH } \\
\text { COEFIICIENT } \\
(\beta) \\
\end{array}$ & $\begin{array}{c}\text { T-Value } \\
(>1.96)\end{array}$ & $\begin{array}{l}\text { P Value } \\
(<0.05)\end{array}$ & $\mathbf{R}^{2}$ & Decision \\
\hline $\mathrm{H}_{02}$ & $\begin{array}{l}\mathrm{L}->\mathrm{OC}->\mathrm{SSO} \\
\text { OC has no significant } \\
\text { mediation effect on } \mathrm{L} \\
\text { and SSO }\end{array}$ & 0.587 & 12.981 & $0.00 * *$ & & $\begin{array}{l}\text { Not Supported } \\
\text { (Rejected) }\end{array}$ \\
\hline
\end{tabular}

Note: Significance level $* * p<0.05$

Key: L= Leadership Skills; OC= Organisational Culture; SSO= students' skill-based learning outcomes

Table 7 above displayed the findings of hypothesis testing $\mathrm{H}_{\mathrm{o}}$. The findings have failed to accept the null hypothesis $H_{02}$. The results of the mediation effect $L->$ OC $\rightarrow$ SSO were $(\beta=0.587, t=12.981, p<0.05)$. The $\beta$ value indicated a positive relationship between the constructs, the t-value was greater than 1.96 , and the $p$-value was significant. Accordingly, the null hypothesis $\mathrm{H}_{02}$ has been rejected. Therefore, the results answered research question 2 and indicated that organisational culture is a mediator that has a significant mediation effect on academic leadership skills of academic leaders and student's skill-based learning outcomes in selected higher education institution in the KSA.

\section{DISCUSSION AND IMPLICATIONS}

The current study has analysed the direct effect of academic leadership skills on student's skill-based learning outcomes. Besides, it focused on examining the mediation effect of organisational culture on academic leadership skills and student's skill-based learning outcomes in selected higher education institution in the KSA.

The findings from the hypotheses testing for the first hypothesis implied that there is no direct and significant effect of academic leadership skills on students' skill-based learning outcomes in selected higher education institution in the KSA. This finding corresponded with the evidence presented by Barker (2007), Bell et al. (2003), Leithwood et al. (2010), Leithwood et al. (2004), Leithwood and Jantzi, (2008), Pina et al. (2015), Sebastian and Allensworth (2012), and Southwell and Morgan (2009). These studies concluded that school leaders have an indirect effect on students' outcomes.

In addition, studies by Alfraih (2014), Al-Safran et al. (2014), Balwant (2016), Yang and Wei, (2009), Day et al. (2016), Harrison (2011), Pina et al. (2015), and Robinson et al. (2008) pointed out that leadership skills, such as transformational and transactional leadership skills can impact directly and indirectly on student learning outcomes. Transformational leadership has an indirect effect on student learning outcomes, while transactional leadership has a direct impact on students' outcomes. Therefore, the current findings in line with the previous results of Alfraih (2014), Al-Safran et al. (2014), Balwant (2016), Yang and Wei, (2009), Day et al. (2016), Harrison (2011), and Pina et al. (2015) in term of indirect effect between transformational leadership skills and students learning outcomes.

The findings from the second hypothesis indicated that organisational culture mediates the effect of academic leadership skills on student skill-based learning outcomes in selected higher education institution in the KSA. The earlier studies did not test precisely on the mediation role of organisational culture on academic leadership skills on student skill-based learning outcomes. There were only several studies that analysed the mediation effect of organisational culture in higher education from different angles. Thesis studies indicated that organizational culture plays a significant mediation role in higher education. It also impacts positively on the performance and outcomes in higher education. Therefore, the current findings are in line with the findings of Leithwood and Jantzi (2000), Li et al. (2018) and Ogbonna and Harris (2000) who clarified that that organisational culture plays a 


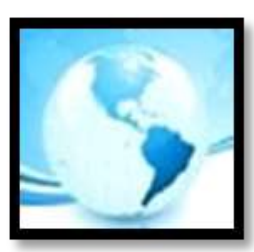

\section{MALAYSIAN ONLINE JOURNAL OF EDUCATIONAL MANAGEMENT (MOJEM)}

significant mediation role. Besides, Leithwood and Jantzi (2000) pointed out that organisational culture has a mediating effect between transformational leadership and student engagement. They stated that transformational leadership has an indirect impact on student engagement. These findings referred that organisational culture plays a mediating role in helping leaders to impact on students positively. Clearly, the current finding is supported by previous findings of Leithwood and Jantzi (2000), Li et al. (2018) and Ogbonna and Harris (2000). Based on the discussion above, the findings in the current study correspond with the existing literature in terms of the indirect effect of leadership skills on students' outcomes through mediation role of organisational culture.

The findings of the present study will contribute to the body of literature that examines the effect of academic leadership skills on student skill-based learning outcomes through mediation effect of organisational culture. Previous literature pointed out that transformational leadership skills and transactional leadership skills are both critical for leaders in educational sectors. This was also supported by the current study that clarified that transformational and transactional leadership skills are significant in higher education. In addition, past studies implied that the OCAI (Cameron \& Quinn, 2011) is a useful instrument in higher education that it can impact positively on both academic leadership skills and students' skills outcomes. Besides, the findings also presented that the Classification Scheme of Learning Outcomes proposed by Kraiger et al. (1993) is a suitable model to measure students' skills-based learning outcomes in higher education. This study has a theoretical implication, which contributes to the body of literature. It has confirmed the significance mediation role of organisational culture in the context of higher education.

Moreover, the findings have the potential to reflect on the Ministry of Education, higher educational leaders, higher education students, officials, and practitioners. The findings provided a meaningful conclusion about the mediation role of organisational culture in higher education. Thus, the current findings will help policymakers to include that in developing plans and improve programmes for academic leaders and students in higher education.

\section{CONCLUSION AND RECOMMENDATIONS}

The findings of the present research have indicated the indirect effect between academic leadership skills and student's skill-based learning outcomes through organisational culture in selected higher education institution in the KSA. The findings clarified that organisational culture plays a significant mediation role on academic leadership skills and students' skill-based learning outcomes.

Therefore, the ministry of education and institutes of higher education must pay more attention to the significant role of organisational culture in higher education. Academic leaders are recommended to employ organisational culture in their executive and development plans as it has a positive effect on students learning outcomes in higher education. Future studies are recommended to examine the mediation effect of organisational culture on other variables in higher education. It is also recommended to analyse these variables in different institutes of higher education. Ultimately, it is necessary for future studies to examine whether the demographic variables can moderate the relationship between these variables.

\section{REFERENCES}

Alarcón, D., Sánchez, J. A., \& De Olavide, U. (2015). Assessing convergent and discriminant validity in the ADHD-R IV rating scale: User-written commands for Average Variance Extracted (AVE), Composite Reliability (CR), and Heterotrait-Monotrait ratio of correlations (HTMT). In Spanish STATA Meeting.

Albutti, D. A. (2014). Leadership competencies of the academic heads of departments at Ha'il University. Journal of Educational \& Psychological Sciences, 15(2), 629-662. doi:10.12785/jeps/150219 


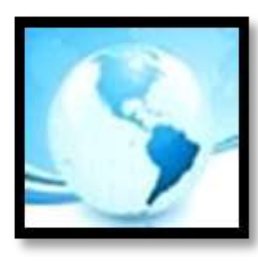

\section{MALAYSIAN ONLINE JOURNAL OF} EDUCATIONAL MANAGEMENT

\section{(MOJEM)}

Alfraih, F. (2014). The role of transformational leadership in influencing students' outcomes in public secondary schools in Kuwait. Retrieved from http://ezproxy.um.edu.my:2048/login?url=https://search.proquest.com/docview/1779550023?accountid $=28930$

Al-Safran, E., Brown, D., \& Wiseman, A. (2014). The effect of principal's leadership style on school environment and outcome. Research in Higher Education Journal, 22, 1-19.

Alsarahani, H. M. (2012). The prevalent of organizational culture in the Universities of Aljoaf and Haial from the perspectives of faculty members and its relation with their motivation to work. Jordan: Alyarmok University.

Alshayea, A. (2012). Improvement of the quality assurance in Saudi higher education. Procedia - Social and Behavioral Sciences, 47, $2234-2236$.

Alshibani, A., \& Alatwi, A. (2011). Measuring the organization education and identifying its gap in the educational organization an applied study in Karbala University. Al-Qadisiyah Journal for Administrative and Economic, 13(1) 65-37. ISSN: 1816917123129883

Altalhi, M. (2012). The required planning competency for secondary school principals in Taif, perceived by educational supervisors. (Master's thesis, Umm Al-Qura University, Makkah). Retrieved from http://libback.uqu.edu.sa/hipres/futxt/14530.pdf

Amanchukwu, R., Stanley, G., \& Ololube, N. (2015). A review of leadership theories, principles and styles and their relevance to educational management. Management, 5(1) 6-14.

Balwant, P. T. (2016). Transformational instructor-leadership in higher education teaching: a meta-analytic review and research agenda. Journal of Leadership Studies, 9(4), 20-42.

Barker, B. (2007). The leadership paradox: Can school leaders transform student outcome. School Effectiveness and School Improvement, 18(1), 21-43.

Bass, B. M., \& Avolio, B. J. (1994). Improving organisational effectiveness through transformational leadership. Thousand Oaks, CA: Sage.

Bell, L., Bolam, R., \& Cubillo, L. (2003). A systematic review of the impact of school headteachers and principals on student outcomes. London: EPPI-Centre, Social Science Research Unit, London Institute of Education.

Bennett, S., \& Valdes, J. (2006). A study of the effectiveness of a diverse workforce within non-profit organizations serving older adults: An analysis of the impact of leadership styles and organizational culture. (Unpublished Doctoral Dissertation). Capella University, Minneapolis, Minnesota.

Cameron, K. S., \& Quinn, R. E. (2011). Diagnosing and changing organizational culture: Based on the competitive values framework (3rd ed.). San Francisco: Jonney-Bass.

Carless, S. A., Wearing, A. J., \& Mann, L. (2000). A short measure of transformational leadership. Journal of Business and Psychology, 14(3), 389-405.

Chua, Y. P. (2016). Mastering research methods. Selangor, Malaysia: McGraw-Hill. 


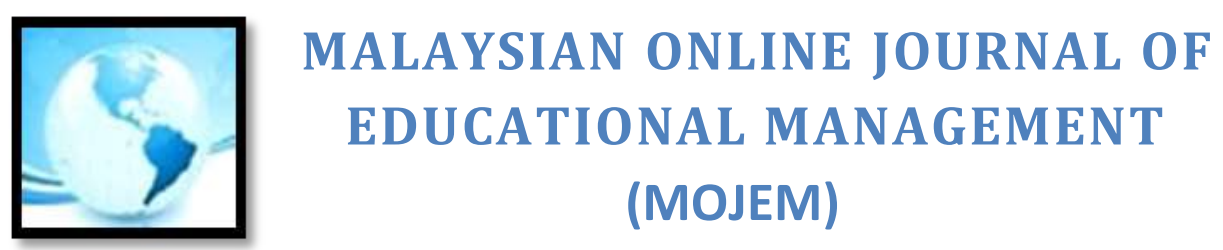

Creswell, J. W. (2018). Research design: Qualitative, quantitative, and mixed methods approaches. Los Angeles: SAGE.

Creswell, J. W. (2012). Educational research: Planning, conducting, and evaluating quantitative and qualitative research. New York, NY: Pearson.

Day, C., Gu, Q., \& Sammons, P. (2016). The impact of leadership on student outcomes. Educational Administration Quarterly, 52(2), 221-258. doi:10.1177/0013161x15616863

Deore, S. T., \& Ratnalikar, D. N. (2010). Academic management and leadership in Indian higher education. In Proceedings of the 6th European Conference on Management Leadership and Governance: ECMLG (p. 2829). Academic Conferences Limited.

Fraenkel, J. R., Wallen, N. E., \& Hyun, H. H. (2015). How to design and evaluate research in education. New York: McGraw-Hill Education.

Fralinger, B., \& Olson, V. (2007). Organizational culture at the university level: A study using the OCAI Instrument. Journal of College Teaching \& Learning, 4(11), 85-98.

Gabbard, B. (2017). Student Learning Outcomes: Communication among a State College Faculty and Students (Doctoral dissertation). Retrieved from: Northcentral University Database.

Hair, J. F., Black, W. C., Babin, B. J., \& Anderson, R. E. (2014). Multivariate data analysis. United States of America: Pearson Prentice Hall.

Hair, J. F., Hult, G. T. M., Ringle, C. M., \& Sarstedt, M. (2017). A Primer on Partial Least Squares Structural Equation Modelling (2nd ed.). Thousand Oakes, CA: Sage.

Harrison, J. L. (2011). Instructor transformational leadership and student outcomes. Emerging leadership journeys, $4(1), 82-136$.

Henseler, J., Ringle, C. M., \& Sarstedt, M. (2015). A new criterion for assessing discriminant validity in variancebased Structural Equation Modelling. Journal of the Academy of Marketing Science, 43(1), 115-135.

Imam, A., Abbasi, A. S., Muneer, S., \& Qadri, M. M. (2013). Organizational culture and performance of higher educational institutions: The mediating role of individual readiness for change. European Journal of Business and Management, 5(20), 23-34.

Kraiger, K., Ford, J. K., \& Salas, E. (1993). Application of cognitive, skill-based, and affective theories of learning outcomes to new methods of training evaluation. Journal of Applied Psychology, 78 (2), 311-328.

Leithwood, K., \& Jantzi, D. (2000). The effects of transformational leadership on organizational conditions and student engagement with school. Journal of Educational Administration, 38(2), 112-129.

Leithwood, K., Patten, S., \& Jantzi, D. (2010). Testing a conception of how school leadership influences student learning. Educational Administration Quarterly, 46(5), 671-706.

Leithwood, K., Louis, K., Anderson, S., \& Wahlstrom, K. (2004). Review of research: How leadership influences student learning. New York: The Wallace Foundation. 


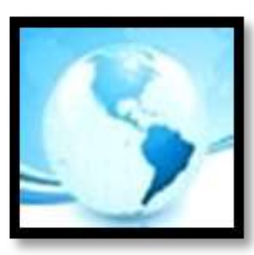

\section{MALAYSIAN ONLINE JOURNAL OF EDUCATIONAL MANAGEMENT (MOJEM)}

Leithwood, K., Louis, K. S., Wahlstrom, K., Anderson, S., Mascall, B., \& Gordon, M. (2010). How successful leadership influences student learning: The second installment of a longer story. In Second International Handbook of Educational Change (pp. 611-629). Springer, Dordrecht.

Leithwood, K., \& Jantzi, D. (2008). Linking leadership to student learning: The contributions of leader efficacy. Educational Administration Quarterly, 44(4), 496-528.

Li, W., Bhutto, T. A., Nasiri, A. R., Shaikh, H. A., \& Samo, F. A. (2018). Organizational innovation: The role of leadership and organizational culture. International Journal of Public Leadership, 14(1), 33-47.

Long, L., \& Mao, M. (2008, October). Impact of leadership style on organizational change: An empirical study in China. Paper presented at the 4th International Conference on wireless communications, networking and mobile computing, Dalian, China, (pp.1-4). doi:10.1109/WiCom.2008.1668

Mutahar, A. Y., Rasli, A. M., \& Al-Ghazali, B. M. (2015). Relationship of transformational leadership, organizational learning and organizational performance. International Journal of Economics and Financial Issues, 5(1S), 406-411.

Northouse, P. G. (2016). Introduction to leadership: Concepts and practice. Los Angeles: SAGE.

Ogbonna, E., \& Harris, L. C. (2000). Leadership style, organizational culture and performance: empirical evidence from UK companies. International Journal of Human Resource Management 11 (4), 766-788.

Pallant, J. (2013). SPSS survival manual. McGraw-Hill Education (UK).

Pina, R., Cabral, I., \& Alves, J. (2015). Principal's leadership on students` outcomes. Procedia-Social and Behavioral Sciences, 197(2015), 949-954. doi: 10.1016/j.sbspro.2015.07.279

Quinn, R. E., \& Spreitzer, G. M. (1991). The psychometrics of the competing values culture instrument and an analysis of the impact of organizational culture on quality of life. In Richard W. Woodman and William A. Pasmore (Eds.), Research in Organizational Change and Development, (5). Greenwich, Conn: JAI Press.

Robinson, V. M., Lloyd, C. A., \& Rowe, K. J. (2008). The impact of leadership on student outcomes: An analysis of the differential effects of leadership types. Educational Administration Quarterly, 44(5), 635-674.

Saudi Ministry of Education. (2019). Higher Education. Retrieved from https://www.moe.gov.sa/en/Pages/default.aspx

Sebastian, J., \& Allensworth, E. (2012). The influence of principal leadership on classroom instruction and student learning: A study of mediated pathways to learning. Educational Administration Quarterly, 48(4), 626-663.

Shahmandi, E. I., Silong, A. D., \& Ismail, L. A. (2012). Level of competencies, gender and leadership effectiveness in a research university. Management Research and Practice, 4(1), 63-73.

Sheikhalizadeh, M., \& Piralaiy, E. (2017). The effects of organizational culture on university's academic staff knowledge management. MOJEM: Malaysian Online Journal of Educational Management, 4(1), 17-31.

Southwell, D., \& Morgan, W. (2009). Leadership and the impact of academic staff development and leadership development on student learning outcomes in higher education: A review of the literature: A report for the 


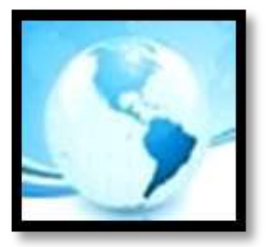

\section{MALAYSIAN ONLINE JOURNAL OF EDUCATIONAL MANAGEMENT (MOJEM)}

Australian Learning and Teaching Council (ALTC). QUT Department of Teaching and Learning Support Services.

Tierney, W. G. (1988). Organizational culture in higher education: Defining the essentials. The Journal of Higher Education, 59(1), 2-21.

Vasyakin, B. S., Ivleva, M. I., Pozharskaya, Y. L., \& Shcherbakova, O. I. (2016). A study of the organizational culture at a higher education institution [Case Study: Plekhanov Russian University of Economics (PRUE)]. International Journal of Environmental and Science Education, 11(10), 11515-11528.

Yang, C., \& Wei, Y. (2009, December). An empirical study of the relationship among leadership style, psychological empowerment and service innovation. Paper presented at the International Conference on Information Management, Innovation Management and Industrial Engineering, Xi'an, China, (pp.386-390) doi:10.1109/ICIII.2009.250

Yeung, A. O., Brockbank, J. W., \& Ulrich, D. O. (1991). Organizational culture and human resources practices: An empirical assessment. In Richard W. Woodman and William A. Pasmore (Eds.), Research in Organizational Change and Development, (5). Greenwich, Conn: JAI Press.

Yukl, G. A. (2013). Leadership in organizations. Upper Saddle River, NJ: Pearson. 